\title{
The Effect of School-Based Management and Teacher Working Group Activities on Teacher Performance in SD Negeri Cluster 4, Kayuagung District
}

\author{
Masnarani $^{\left.1^{*}\right)}$, Bukman lian², Mulyadi² \\ ${ }^{I}$ SD Negeri 2 Teloko \\ ${ }^{2}$ Universitas PGRI Palembang \\ *Corresponding author. Email:masnarani918@gmail.com
}

\begin{abstract}
This study aimed to determine the effect of school-based management and teacher working groups on teacher performance at, Elementary School Cluster 4 Kayuagung District. This research was quantitative descriptive. The sample in the study was 64 respondents with data collection techniques in the form of a questionnaire. The data were analyzed by using SPSS program. The results showed that: 1) there is a significant effect of School-Based Management on teacher performance, 2) there is a significant effect of the Teacher Working Group on teacher performance, 3) There is a significant influence between School-Based Management and Teacher Working Group on teacher performance. In brief, school-based management and teacher working group could influence the teacher's performance.
\end{abstract}

Keywords: School-Based Management, Working Group, Teacher Performance

\section{INTRODUCTION}

Every human life requires good management. All aspects personally, especially professionals must be able to manage everything appropriately. The management process is part of management. Management is the art of regulating the process of utilizing human resources and other sources effectively and efficiently to achieve certain goals [1]. This means studying management as well as learning how to influence other people to do something. Law Number 20 of 2003 concerning the National Education System in article 51 paragraph (1) states that school or madrasah-based management is a form of education management autonomy in education units, which in this case the head of schools or madrasah and teachers are assisted by school committees or madrasahs in managing national education activities [2].

Based on the results of observations and interviews conducted by the researcher at State Elementary Schools (SD) who are members of Cluster 4 Kayuagung Found the fact that perceptions regarding the application of school-based management are still very varied, this is due to the lack of understanding of teachers regarding good school-based management in the implementation process. Not optimal work results from teachers who are actively involved in teacher working group activities, so that it needs emphasis in its implementation, the learning administration organized by the teacher is not yet optimal, as evidenced by the difficulty of the researcher finding learning completeness in a relatively short time.

Performance is the result of work in quality and quantity achieved by an employee in carrying out his assigned task [3]. According to [4], the teacher working group is a collection of activities carried out by the teacher community in a cluster that has characteristics Relatively the same task field, usually consisting of groups of classroom teachers, subject teachers, and/or guidance and counseling teachers.

Several related studies include Noor in 2017, researching the influence of school principal leadership patterns and the implementation of school-based management on teacher performance at SD Negeri Cipanengah Cipta Bina Mandiri, Sukabumi City. The results of the study conducted provided information that there was a significant positive influence on the leadership pattern of the principal on teacher performance at SD Negeri Cipanengah, Sukabumi City. There was a positive influence on the implementation of SBM on teacher performance at SD Negeri Cipanengah Sukabumi City. There is a significant positive effect of 
school coconut leadership and the implementation of school-based management on teacher performance.

The same research was conducted by [5] which entitled The influence of School-Based Management and Work Motivationtowards Teacher's Performance. The result of the research stated that school-based management is able to have a positive and significant impact on teacher performance. Similarities in research by [4], conducted a study that focused on the Implementation of School-Based Management in mproving the quality of education. The results obtained from these studies state that school-based management that is implemented properly can improve the quality of education as a whole.

\section{METHODS}

\subsection{Research Method}

The research method used in this research was the descriptive method with a quantitative approach, according to [6] descriptive method is a method used to look for the elements, characteristics, and characteristics of a phenomenon. The population in this study were teachers and principals of public elementary schools who were members of Cluster 4 Kayuagung as many as 84 respondents consisting of 20 trial samples and 64 main samples. The data analysis technique used the classical assumption test, that is the normality test and heteroscedasticity test.

\subsection{Research Subject}

The research subjects were all teachers and headmasters of public schools in cluster 4, Kayuagung sub-district.

Table 1. Research Sample

\begin{tabular}{|l|l|c|c|}
\hline No & Information & $\begin{array}{l}\text { Main } \\
\text { Sample }\end{array}$ & $\begin{array}{l}\text { Trial } \\
\text { sample }\end{array}$ \\
\hline 1 & SD N 1 Tanjung Lubuk & 8 & \\
\hline 2 & SD N 1 Serigeni & 10 & \\
\hline 3 & SD N 2 Serigeni & 12 & \\
\hline 4 & SD N 1 Serigeni Baru & 9 & \\
\hline 5 & SD N 2 Serigeni Baru & & 9 \\
\hline 6 & SD N 1 Tanjung Serang & 8 & \\
\hline 7 & SD N 2 Tanjung Serang & 8 & \\
\hline 8 & SD N 1 Teloko & & 11 \\
\hline 9 & SD N 2 Teloko & 9 & \\
\hline & Jumlah & 64 & 20 \\
\hline
\end{tabular}

Source: DUK at Cluster 4 Regional Schools

Based on the data found in Table above, it is clear that this study used 64 teachers as the research sample, which were spread over 7 (seven) public elementary schools in Kayuagung District.

\subsection{Data Analysis Technique}

The data obtained by the researcher in conducting research, then processed so that the data has meaning. The stage, the analysis, was to first test the preconditions to determine the right formula in carrying out statistical analysis.

Furthermore, hypothesis testing was carried out in accordance with the criteria that meet the prerequisite test results. The data obtained in the implementation of the research were then processed so that the data has meaning through the Classical Assumption Test which was a pre-requisite test to determine the appropriate formula to use in order to test the hypothesis, that is the Heteroscedasticity Test. This test was carried out using the help of the SPSS program.

\section{Hypothesis Testing}

After the prerequisite testing has been carried out, then it was continued with hypothesis testing. This test was done to prove and answer the formulation of the research problem. To test the hypothesis partially it was done through the " $\mathrm{t}$ " test, while to test simultaneously multiple regression was used with the "F" test. The multiple linear regression equation used was, $\hat{Y}=a+$ $\mathrm{b} 1 \mathrm{X} 1+\mathrm{b} 2 \mathrm{X} 2+\mathrm{e}$.

\section{RESULTS AND DISCUSSION}

The research implementation process by distributing questionnaires was carried out in stages. The questionnaires that have been distributed to the research sample are then collected again, to be recapitulated and analyzed further.

Research hypothesis testing can be done using parametric statistical analysis through the " $t$ " test for partial or individual testing and the "F" test for simultaneous or collective hypothesis testing.

Description of research data

Table 2. Frequency Distribution School Based Management

\begin{tabular}{|cc|c|c|c|c|}
\hline & & Frequency & Percent & Valid Percent & $\begin{array}{c}\text { Cumula } \\
\text { tive Percent }\end{array}$ \\
\hline Va & 73,91 & 2 & 3,1 & 3,1 & 3,1 \\
Lid & 74,78 & 3 & 4,7 & 4,7 & 7,8 \\
& 75,65 & 4 & 6,3 & 6,3 & 14,1 \\
& 76,52 & 5 & 7,8 & 7,8 & 21,9 \\
77,39 & 3 & 4,7 & 4,7 & 26,6 \\
78,26 & 7 & 10,9 & 10,9 & 37,5 \\
79,13 & 9 & 14,1 & 14,1 & 51,6 \\
80,00 & 5 & 7,8 & 7,8 & 59,4 \\
80,87 & 3 & 4,7 & 4,7 & 64,1 \\
81,74 & 7 & 10,9 & 10,9 & 75,0 \\
82,61 & 6 & 9,4 & 9,4 & 84,4 \\
83,48 & 4 & 6,3 & 6,3 & 90,6 \\
84,35 & 2 & 3,1 & 3,1 & 93,8 \\
85,22 & 4 & 6,3 & 6,3 & 100,0 \\
Total & 64 & 100,0 & 100,0 & \\
\hline
\end{tabular}

Source: processed data (October 2020) 
If seen properly, in the frequency column the highest value is 79.13 as many as 9 people or $14.1 \%$ of the total sample and included in the good category. When viewed, there are only 4 (four) people who state that the implementation of school-based management is very good. This can be seen from the final score $\geq$ 85.00. The highest value was achieved by the respondent.

The research for the variable implementation of school-based management was 85.22 and the lowest score was 73.91. The comparison of the final scores obtained by each school regarding the application of school-based management can be seen in the following table.

Table 3. Comparison of the Final Score of SchoolBased Management Variables

\begin{tabular}{|c|l|c|}
\hline No & \multicolumn{1}{|c|}{ Information } & $\begin{array}{c}\text { School-Based } \\
\text { Management }\end{array}$ \\
\hline 1 & SD N 1 Tanjung Lubuk & 80,33 \\
\hline 2 & SD N 1 Serigeni & 80,44 \\
\hline 3 & SD N 2 Serigeni & 79,93 \\
\hline 4 & SD N 1 Serigeni Baru & 78,94 \\
\hline 5 & SD N 1 Tanjung Serang & 79,78 \\
\hline 6 & SD N 2 Tanjung Serang & 81,09 \\
\hline 7 & SD N 2 Teloko & 77,78 \\
\hline \multicolumn{2}{|c|}{ Source: processed data (October 2020) }
\end{tabular}

For the teacher working group activity variable as the second independent variable (X2), the frequency distribution of the final score according to the perception of the research sample can be seen in the following table.

Table 4. Frequency Distribution of Teacher Working Group Activities

\begin{tabular}{|cc|c|c|c|c|}
\hline & $\begin{array}{c}\text { Frequ } \\
\text { ency }\end{array}$ & $\begin{array}{c}\text { Per } \\
\text { cent }\end{array}$ & Valid Percent & $\begin{array}{c}\text { Cumula } \\
\text { tive Percent }\end{array}$ \\
\hline Valid & 73,04 & 1 & 1,6 & 1,6 & 1,6 \\
& 73,91 & 1 & 1,6 & 1,6 & 3,1 \\
& 74,78 & 3 & 4,7 & 4,7 & 7,8 \\
75,65 & 1 & 1,6 & 1,6 & 9,4 \\
76,52 & 2 & 3,1 & 3,1 & 12,5 \\
77,39 & 5 & 7,8 & 7,8 & 20,3 \\
78,26 & 5 & 7,8 & 7,8 & 28,1 \\
79,13 & 3 & 4,7 & 4,7 & 32,8 \\
80,00 & 10 & 15,6 & 15,6 & 48,4 \\
80,87 & 10 & 15,6 & 15,6 & 64,1 \\
81,74 & 5 & 7,8 & 7,8 & 71,9 \\
82,61 & 5 & 7,8 & 7,8 & 79,7 \\
83,48 & 7 & 10,9 & 10,9 & 90,6 \\
84,35 & 5 & 7,8 & 7,8 & 98,4 \\
86,96 & 1 & 1,6 & 1,6 & 100,0 \\
Total & 64 & 100,0 & 100,0 & \\
\hline
\end{tabular}

The values with the most frequency according to the table above are 80.00 and 80.87 as many as 10 (ten) people respectively. The score achievement is in a good category. There is 1 (one) respondent who stated that the teacher's working group activity was in the very good category, this was seen from the final score of the respondent which was greater than 85.00. The highest score achieved by research respondents related to teacher working group activities was 86.96 and the lowest score was 73.04.

When compared separately in relation to the achievement of the final score of the respondents in each school that was the research sample, it can be seen in the following table.

Table 5. Comparison of the Final Score of Teacher Working Group Activities

\begin{tabular}{|c|l|c|}
\hline No & \multicolumn{1}{|c|}{ Information } & $\begin{array}{c}\text { Teacher Working } \\
\text { Group }\end{array}$ \\
\hline 1 & SD N 1 Tanjung Lubuk & 80,54 \\
\hline 2 & SD N 1 Serigeni & 81,48 \\
\hline 3 & SD N 2 Serigeni & 80,36 \\
\hline 4 & SD N 1 Serigeni Baru & 79,52 \\
\hline 5 & SD N 1 Tanjung Serang & 81,20 \\
\hline 6 & SD N 2 Tanjung Serang & 81,09 \\
\hline 7 & SD N 2 Teloko & 77,97 \\
\hline
\end{tabular}

Source: processed data (October, 2020)

Likewise with the teacher performance variables in SD Negeri in cluster 4, Kayuagung District. For this variable, it is described in such a way as to provide a complete picture of the condition of teacher performance in the schools that are the research sample. More details can be seen in the following tablet.

Table 6. Frequency Distribution of Teacher Performance Variables

\begin{tabular}{|cc|c|c|c|c|}
\hline & & Frequency & Percent & Valid Percent & $\begin{array}{c}\text { Cumula } \\
\text { tive Percent }\end{array}$ \\
\hline Valid & 73,04 & 2 & 3,1 & 3,1 & 3,1 \\
& 73,91 & 1 & 1,6 & 1,6 & 4,7 \\
& 74,78 & 1 & 1,6 & 1,6 & 6,3 \\
75,65 & 3 & 4,7 & 4,7 & 10,9 \\
76,52 & 5 & 7,8 & 7,8 & 18,8 \\
77,39 & 8 & 12,5 & 12,5 & 31,3 \\
78,26 & 4 & 6,3 & 6,3 & 37,5 \\
79,13 & 6 & 9,4 & 9,4 & 46,9 \\
80,00 & 6 & 9,4 & 9,4 & 56,3 \\
80,87 & 7 & 10,9 & 10,9 & 67,2 \\
81,74 & 6 & 9,4 & 9,4 & 76,6 \\
82,61 & 8 & 12,5 & 12,5 & 89,1 \\
83,48 & 5 & 7,8 & 7,8 & 96,9 \\
84,35 & 1 & 1,6 & 1,6 & 98,4 \\
87,83 & 1 & 1,6 & 1,6 & 100,0 \\
Total & 64 & 100,0 & 100,0 & \\
\hline
\end{tabular}

Source: processed data (October 2020)

In the table above, it is clear that the highest 
frequency is at the final score of 82.61 and 77.39 , respectively, as many as 8 (eight) research samples. If further analyzed, it is known that 1 (one) teacher is declared to have very good performance. The highest score for teacher performance in SD Negeri in cluster 4 of Kayuagung District was 87.83. While the lowest final score for the teacher performance variable is 73.04 which is still included in the good performance category.

To see the comparison of the achievement of the final score of teacher performance in each school, it can be seen in the following table.

Table 7. The Posttest Teacher Performance

\begin{tabular}{|c|l|c|}
\hline No & \multicolumn{1}{|c|}{ Note } & $\begin{array}{c}\text { Teacher } \\
\text { Performance }\end{array}$ \\
\hline 1 & SD N 1 Tanjung Lubuk & 79,57 \\
\hline 2 & SD N 1 Serigeni & 80,35 \\
\hline 3 & SD N 2 Serigeni & 79,64 \\
\hline 4 & SD N 1 Serigeni Baru & 79,32 \\
\hline 5 & SD N 1 Tanjung Serang & 79,57 \\
\hline 6 & SD N 2 Tanjung Serang & 81,20 \\
\hline 7 & SD N 2 Teloko & 78,07 \\
\hline
\end{tabular}

Source: processed data (October 2020)

The table above is a comparison of the achievement of the final average score for the interschool teacher performance variable that was the research sample. The table can also be depicted with a diagram, so as to provide information that is more easily visible.

It is clearer about the comparison of the scores obtained by each school when viewed as a whole, which can be seen in the following table.

Table 8. Comparison of Final Score

\begin{tabular}{|c|l|c|c|c|}
\hline No & \multicolumn{1}{|c|}{ Information } & $\begin{array}{c}\text { School-Based } \\
\text { Management }\end{array}$ & $\begin{array}{c}\text { KKG } \\
\text { Activity }\end{array}$ & $\begin{array}{c}\text { Peacher } \\
\text { ce }\end{array}$ \\
\hline 1 & $\begin{array}{l}\text { SD N 1 Tanjung } \\
\text { Lubuk }\end{array}$ & 80,33 & 80,54 & 79,57 \\
\hline 2 & SD N 1 Serigeni & 80,44 & 81,48 & 80,35 \\
\hline 3 & SD N 2 Serigeni & 79,93 & 80,36 & 79,64 \\
\hline 4 & $\begin{array}{l}\text { SD N 1 Serigeni } \\
\text { Baru }\end{array}$ & 78,94 & 79,52 & 79,32 \\
\hline 5 & $\begin{array}{l}\text { SD N 1 Tanjung } \\
\text { Serang }\end{array}$ & 79,78 & 81,20 & 79,57 \\
\hline 6 & $\begin{array}{l}\text { SD N 2 Tanjung } \\
\text { Serang }\end{array}$ & 81,09 & 81,09 & 81,20 \\
\hline 7 & SD N 2 Teloko & 77,78 & 77,97 & 78,07 \\
\hline
\end{tabular}

Source: processed data (October 2020)
Testing Data Analysis Statements Normality test

From the results of the normality test, the following results are obtained

Table 9 . Data Normality Test Results

One-Sample Kolmogorov-Smirnov Test

\begin{tabular}{|c|c|c|}
\hline & Unstandardized Residual \\
\hline $\mathrm{N}$ & & 64 \\
\hline Normal & Mean & 0000000 \\
\hline Parameters ${ }^{\mathrm{a}, \mathrm{b}}$ & Std. Deviation & 1,66984881 \\
\hline Most Extreme & Absolute & ,096 \\
\hline Differences & $\begin{array}{l}\text { Positive } \\
\text { Negative }\end{array}$ & $\begin{array}{r}, 096 \\
-.054\end{array}$ \\
\hline Test Statistic & & 096 \\
\hline Asymp. Sig. (2 & 2-tailed) & $200^{\mathrm{c}, \mathrm{d}}$ \\
\hline
\end{tabular}

a. Test distribution is Normal.

b. Calculated from data.

c. Lilliefors Significance Correction.

$\mathrm{d}$. This is a lower bound of the true significance.

Source: processed data (October 2020)

Based on the test results as shown in the table above, it can be concluded that the data distribution in this study is normally distributed. Therefore, hypothesis testing can be done through parametric statistical analysis. In this study, the significance value is 0.050 , which means $\geq 0.05$, and it is clear that the criteria for normality of data distribution have been met. The conclusion is that the data is normally distributed according to predetermined criteria, that if the significance value is $\geq 0.05$ then the data is normally distributed.

\section{Hypothesis Testing 1}

The results of the simple linear regression test, which is partial hypothesis testing, that is testing $\mathrm{X} 1$ against Y.Based on the results of the tests that have been carried out, it is known that the $t$ value for the school-based management variable is 9.398> $t$ Table which is 1.999 which means that the alternative hypothesis (Ha) for testing hypothesis 1 is stated to be accepted. Therefore, it is stated that the implementation of school-based management has a positive and significant effect on the performance of teachers in SD Negeri in cluster 4, Kayuagung District, Ogan Komering Ilir District. The correlation coefficient or the magnitude of the relationship between the variables of school-based management implementation on teacher performance is $58.8 \%$, which means it has a high enough influence. 
The table above is the result of simple linear regression testing, that is partial hypothesis testing, that is testing X1 against Y.Based on the results of the tests that have been carried out, it is known that the $t$ value for the school-based management variable is 9.398> $t$ Table is 1.999 which means that the alternative hypothesis ( $\mathrm{Ha}$ ) for testing hypothesis 1 is declared accepted. Therefore, it is stated that the application of school-based management has a positive and significant effect on the performance of teachers in SD Negeri in cluster 4, Kayuagung District, Ogan Komering Ilir District [7] [8].

Other proof can also be done by looking at the significance value, which is $0.000<0.05$, which means that the implementation of school-based management has a positive and significant effect on the performance of teachers in SD Negeri in cluster 4, Kayuagung District, Ogan Komering Ilir District. Other proof can also be done by looking at The significance value is $0.000<0.05$, which means that the alternative hypothesis (Ha) for $\mathrm{H} 1$ is accepted. To find out the magnitude of the correlation coefficient or the magnitude of the relationship and the determinant coefficient or the magnitude of the influence of the application of school-based management on the performance of teachers in public elementary schools in cluster 4, Kayuagung District, Ogan Komering Ilir Regency, can be seen in the following table.

Table 11. The Correlational Coefficient and the Determinant Coefficient of Hypothesis 1 (H1) Model Summary

\begin{tabular}{|l|r|r|r|r|}
\hline $\begin{array}{l}\text { Mo } \\
\text { Del }\end{array}$ & $\mathrm{R}$ & $\mathrm{R}$ Square & $\begin{array}{c}\text { Adjusted R } \\
\text { Square }\end{array}$ & $\begin{array}{c}\text { Std. Error of the } \\
\text { Estimate }\end{array}$ \\
\hline 1 &, 767 &, 588 &, 581 & 1,93192 \\
\hline
\end{tabular}

Source: processed data (October 2020).

\section{Hypothesis Testing 2}

From the results of Hypothesis 2 Testing "t-test" value is 10.420 which is the $t$ count for the variable teacher working group activities. From this value, it is interpreted at the value of $\mathrm{t}$ Table which is equal to 1.999, which means tcount> t table; 10,420> 1,999 . Based on this, it is concluded that the alternative hypothesis is accepted, which means that the teacher working group activities have a positive and significant effect on teacher performance in SD Negeri in cluster 4, Kayuagung District. The determinant coefficient or the magnitude of the influence of the variable teacher working group activities on teacher performance in SD Negeri in cluster 4, Kayuagung District, is $63.7 \%$

Hypothesis testing 2 in this study is intended to test the following hypotheses:
Table 10. Results of Testing Hypothesis 1 "T-test" Coefficients $^{\mathrm{a}}$

\begin{tabular}{|c|c|c|c|c|c|}
\hline \multirow[b]{2}{*}{ Model } & \multicolumn{2}{|c|}{$\begin{array}{c}\text { Unstandardized } \\
\text { Coefficients }\end{array}$} & \multirow{2}{*}{$\begin{array}{c}\begin{array}{c}\text { Standardized } \\
\text { Coefficients }\end{array} \\
\text { Beta }\end{array}$} & \multirow[b]{2}{*}{$t$} & \multirow[b]{2}{*}{ Sig. } \\
\hline & $\mathrm{B}$ & Std. Error & & & \\
\hline $\begin{array}{ll}1 \text { Constant } \\
\\
\text { School- } \\
\text { Based } \\
\text { Manage } \\
\text { ment }\end{array}$ & 20,354 & 6,315 & ,767 & 3,223 &, 002 \\
\hline
\end{tabular}
Source: processed data (October 2020)

The results obtained from testing the hypothesis above are as follows:

Table 12. Results of Testing Hypothesis 2 "t-test" Source: processed data (October 2020)

Coefficients $^{\mathbf{a}}$

\begin{tabular}{|l|c|c|c|c|c|}
\hline \multirow{2}{*}{ Model } & \multicolumn{2}{|c|}{$\begin{array}{c}\text { Unstandardized } \\
\text { Coefficients }\end{array}$} & $\begin{array}{c}\text { Standardized } \\
\text { Coefficients }\end{array}$ & & \\
\cline { 2 - 5 } & $\mathrm{B}$ & Std. Error & Beta & $\mathrm{t}$ & Sig. \\
\hline $\begin{array}{l}\text { 1 (Constant) } \\
\begin{array}{c}\text { Activity of } \\
\text { Teacher's } \\
\text { Group }\end{array}\end{array}$ & 14,404 & 6,266 & & 2,299 &, 025 \\
\hline
\end{tabular}

a. Dependent Variable: Teacher Performance

In the " $t$ " column in the table above, it is known that the value is 10.420 , which is the t-count value for the teacher working group activity variable. From this value, it is interpreted at the value of $t$ Table which is equal to 1.999 , which means tcount $>\mathrm{t}$ table; 10,420> 1,999. Based on this, it is concluded that the alternative hypothesis is accepted, which means that the activities of the teacher working group have a positive and significant effect on the performance of teachers in SD Negeri in cluster 4, Kayuagung District.

To confirm these results, it can also be seen that the significance value is $0.000<0.05$, which means that the alternative hypothesis (Ha) is accepted and the statistical hypothesis (H0) is rejected. To find out the magnitude of the relationship and the influence of the teacher working group activity variables on the performance of teachers in SD Negeri in cluster 4, Kayuagung District, can be seen in the following table.

Table 13. Correlational Coefficient and Determinant Coefficient of Hypothesis 2 (H2) Model Summary

\begin{tabular}{|l|c|r|r|r|}
\hline $\begin{array}{l}\text { Mo } \\
\text { Del }\end{array}$ & R & R Square & $\begin{array}{c}\text { Adjus } \\
\text { ted R Square }\end{array}$ & $\begin{array}{r}\text { Std. Error of } \\
\text { the Estimate }\end{array}$ \\
\hline 1 &, 798 &, 637 &, 631 & 1,81355 \\
\hline
\end{tabular}

a. Predictors: (Constant), Teacher Working Group Activities

Source: processed data (October 2020)

In column $\mathrm{R}$ in the table above, it is known that there is a value of 0.798 , which means the magnitude of the correlation coefficient or the magnitude of the 
relationship between teacher working group activities and teacher performance is $79.8 \%$. The magnitude of the relationship is included in the category that is close or high. In the $\mathrm{R}$ square column, there is a value of 0.637 , which means the determinant coefficient or the magnitude of the influence of the teacher working group activity variable on teacher performance in SD Negeri in cluster 4, Kayuagung District, is $63.7 \%$ and is included in the category of high influence.

\section{Hypothesis Testing 2}

Simultaneous testing is carried out through the "F" test. there is a value of 66.909> FTabel of 3.148, which means that there is a positive and significant influence on the implementation of school-based management and teacher working group activities simultaneously on the performance of SD Negeri teachers in Cluster 4, Kayuagung District. The determinant coefficient is 0.687 , which means that the simultaneous application of school-based management and teacher working group activities to the performance of public elementary school teachers in Cluster 4, Kayuagung District is $68.7 \%$. The results obtained from these tests can be seen in the following table.

Table 14. Results of Testing Hypothesis 3 "F Test" ANOVA

\begin{tabular}{|c|c|c|c|c|c|}
\hline Model & $\begin{array}{c}\text { Sum of } \\
\text { Squares }\end{array}$ & $\mathrm{df}$ & $\begin{array}{c}\text { Mean } \\
\text { Square }\end{array}$ & $\mathrm{F}$ & Sig. \\
\hline $1 \quad$ Regression & 385,371 & 2 & 192,686 & 66,909 &, $000^{\mathrm{b}}$ \\
\hline Residual & 175,669 & 61 & 2,880 & & \\
\hline Total & 561,040 & 63 & & & \\
\hline
\end{tabular}

a. Dependent Variable: Teacher Performance b. Predictors: (Constant), Teacher Working Group, School-based management

Table 15. Correlational Coefficient and Determinant Coefficient of Hypothesis 3 (H3) Model Summary

\begin{tabular}{|c|c|c|c|c|}
\hline $\begin{array}{c}\text { Mo } \\
\text { del }\end{array}$ & $\mathrm{R}$ & $\mathrm{R}$ Square & $\begin{array}{c}\text { Adjusted R } \\
\text { Square }\end{array}$ & $\begin{array}{c}\text { Std. Error of the } \\
\text { Estimate }\end{array}$ \\
\hline 1 &, $829^{\mathrm{a}}$ &, 687 &, 677 & 1,69700 \\
\hline
\end{tabular}

Source: processed data (October 2020

The table above is the result of multiple regression analysis. In column $\mathrm{R}$, the value is 0.829 , which means that $82.9 \%$ collectively, the implementation of schoolbased management and teacher working group activities affects the performance of teachers in SD Negeri in cluster 4, Kayuagung District, thus is included in the category of close or high relationship In the R Square column of 0.687 which means the implementation of school-based management and teacher working group activities simultaneously on the performance of SD
Negeri teachers in Cluster 4, Kayuagung District is $68.7 \%$ and is included in the category of high enough influence.

\section{The effect of teacher working group activities on teacher performance}

Hypothesis testing is carried out to obtain a t-count value of 10.420 for the teacher working group activity variable. From this value, it is interpreted at the value of $\mathrm{t}$ Table which is equal to 1.999 , which means tcount $>\mathrm{t}$ table; 10,420>1,999. Based on this, it is concluded that the alternative hypothesis is accepted, which means that the activities of the teacher working group have a positive and significant effect on the performance of teachers in SD Negeri in cluster 4, Kayuagung District [9].

\section{The effect of school-based management and teacher working group activities on teacher performance}

The simultaneous hypothesis testing carried out by the researcher through the $\mathrm{F}$ test, obtained a value of $\mathrm{F}$ count of 66.909> F Tabel of 3.148, which means that there is a positive and significant influence on the implementation of school-based management and teacher working group activities simultaneously on the performance of SD Negeri teachers in Cluster 4, Kayuagung District.

\section{CONCLUSION}

From the results of data analysis and processing and discussion of the findings of this study, there are several things that the researcher concludes. The conclusions meant are: School-based management has a positive and significant impact on the performance of teachers in SD Negeri in cluster 4, Kayuagung District. The t-count value obtained from the test is $9.398>\mathrm{t}$ table which is 1.999 . The magnitude of the influence of school-based management variables on teacher performance is $58.8 \%$ and it is categorized as quite high. Teacher working group activities have a positive and significant effect on teacher performance at public elementary schools in cluster 4, Kayuagung District. Value tcount $>t$ table; $10,420>1,999$. The magnitude of the influence of the variable teacher working group activities on teacher performance is $63.7 \%$ and is in the fairly high category. School-based management and teacher working group activities collectively have a positive and significant effect on teacher performance in SD Negeri in cluster 4, Kayuagung District. The value of F count obtained from testing is 66.909> FTabel of 3.148. The magnitude of influence simultaneously was $68.7 \%$ and it was included in the category of quite high influence. 


\section{REFERENCES}

[1] Hasibuan, M. S. (2012). Manajemen Sumber Daya Manusia. Jakarta: Bumi Aksara

[2] Kementerian Pendidikan Nasional. (2003). Undang-undang Nomor 20 Tahun 2003 tentang Sistem Pendidikan Nasional. Jakarta: Kementerian Pendidikan Nasional

[3] Mangkunegara, A. P. (2013). Manajemen sumber daya manusia perusahaan. Bandung: Remaja Rosdakarya

[4] Eslianna, Lian, B., \& Sari, A. P. (2020). Implementation of School-Based Management in Improving the Quality of Education. International Journal of Progressive Sciences and Technologies Volume 23 Nomor 1, 316-323.

[5] Sultoni, M., Lian, B., \& Mulyadi. (2020). The influence of School-Based management and work motivation towards teacher's performance. International Journal of Educational Review, Volume 2 Nomor 2, 183-191

[6] Suryana. (2010). Metodologi Penelitian. Bandung: Universitas Pendidikan Indonesia.

[7] Noor, I. (2017). Pengaruh pola kepemimpinan kepala sekolah dan implementasi manajemen berbasis sekolah terhadap kinerja guru pada SD Negeri Cipanengah Cipta Bina Mandiri Kota Sukabumi. ADHUM, Volume VII Nomor 2, 147157.

[8] Suharsaputra, U. (2010). Administrasi pendidikan. Kelapa Gunung: Refika Aditia

[9] Mulyasa, E. (2013). Menjadi guru profesional. Bandung: Remaja Rosdakarya. 